\title{
TRANSDERMAL NITROGLYCERIN VERSUS ORAL NIFEDIPINE ADMINISTRATION FOR TOCOLYSIS IN PRETERM LABOUR
}

\author{
Shanthi Rani Balasubramani1, Kameswari Kamatchi ${ }^{2}$
}

${ }^{1}$ Senior Assistant Professor, Department of Obstetrics and Gynaecology, Government Theni Medical College, Theni. ${ }^{2}$ Assistant Professor, Department of Obstetrics and Gynaecology, Government Theni Medical College, Theni.

\begin{abstract}
\section{BACKGROUND}

Preterm labour is defined by the world health organization as the onset of labour in a pregnancy before the completion of 37 weeks of gestation and after 20 weeks of gestation. In about 45 - 50\% of cases of preterm labour, the aetiology remains obscure. So attempts at prevention have not been very encouraging, but arrest of preterm labour continues to be the need of the hour. Currently, main goal for use of tocolytic therapy is to delay the birth so as to allow the use of corticosteroids for accelerating foetal lung maturity and maternal transfer to a tertiary care centre and thereby reducing neonatal morbidity and mortality. There are many number of tocolytic drugs, but unfortunately none has been completely effective because of questionable efficacy and potentially serious side effects outweigh the use of many tocolytic agents.

In this study, comparison of effectiveness of oral nifedipine with transdermal nitroglycerin in the inhibition of preterm delivery is being done.
\end{abstract}

\section{MATERIALS AND METHODS}

Study on tocolysis in preterm labour was conducted in Government Rajaji Hospital from December 2010 to November $2011 ; 100$ women with preterm labour randomly selected from the pregnant women attending antenatal OP and from labour ward from the Department of Obstetrics and Gynaecology, Government Rajaji Hospital, Madurai. Out of which 50 women were recruited for oral nifedipine and another 50 women were recruited for transdermal nitroglycerin patch. If and time needed for tocolysis, prolongation of pregnancy and the neonatal outcomes were observed. The results were tabulated in performed proforma and meticulously analysed.

\section{RESULTS}

The study was designed with a total sample of non-randomly selected 100 women who were in preterm labour, out of which 50 women were allotted for oral nifedipine in Group I and another 50 women were non-randomly selected for transdermal nitroglycerin patch in Group II. The age distribution of the two groups has no significant difference. The maximum number of patients in both groups fall in age group between 20 - 24 years. There is no significant difference in the antenatal care received, parity, distribution of the presenting part and cervical effacement by the 2 groups of patients. Pre-term labour in previous pregnancy was 22\% (11 out of 50) in Group I and 18\% (9 out of 50) in Group II. There is no significant difference in the history of pre-term labour between the 2 groups of patients. Though there was not much significant difference in the gestational age on admission in both groups, the time of prolongation of pregnancy varied considerably in both groups. Mean prolongation with Group I was significant when compared to Group II, in case of cervical dilatation $1 \mathrm{~cm}$ or less than $1 \mathrm{~cm}$. Time needed for Tocolysis ranging between 2 - 12 hours in both the groups. There is significant difference in the incidence of complications among the 2 groups of patients. Among Group I, it was about 6\% and in Group II 22\%. When the gestational age at delivery was compared in both the groups, it differed significantly. There is no much significant difference in the birth weight of the babies in both the groups. The acute tocolytic effect between the 2 groups was significantly different. Only $10 \%$ in Group I delivered within 2 days, but in Group II it was $28 \%$. Admission in neonatal ward differed significantly. Only 7 babies in Group I got admitted in neonatal ward, whereas in Group II 16 babies got admitted. This indicates nifedipine successfully reducing the neonatal admission and had the better perinatal outcome.

\section{CONCLUSION}

Oral nifedipine has a very good role to play in the treatment of acute tocolysis and for prolongation of pregnancy. So it can be considered as the first line drug of choice.

\section{KEYWORDS}

Oral Nifedipine, Tocolysis, Preterm Labour, Pregnancy.

HOW TO CITE THIS ARTICLE: Balasubramani SR, Kamatchi K, Transdermal nitroglycerin versus oral nifedipine administration for tocolysis in preterm labour. J. Evolution Med. Dent. Sci. 2017;6(52):3967-3974, DOI: 10.14260/Jemds/2017/859

Financial or Other, Competing Interest: None.

Submission 23-03-2017, Peer Review 16-06-2017,

Acceptance 23-06-2017, Published 29-06-2017.

Corresponding Author:

Dr. Kameswari Kamatchi,

3/1/9, Vasavi Colony, P. C. Patty, Theni.

E-mail: kskames@yahoo.co.in

DOI: $10.14260 /$ jemds $/ 2017 / 859$

\section{BACKGROUND}

The World Health Organization has estimated that 12.9 million births (or) $9.6 \%$ of all births worldwide were preterm in 2005. In the era of modem obstetrics, despite advancement in all specialities, the delivery of infants in preterm period of gestation is a major factor contributing to perinatal mortality and morbidity. Incidence of preterm birth is about $10-15 \%$. Prematurity contributes also to the reduced quality of life and neurosensory disability, which increases with decreasing gestational age. Preterm birth may have huge psychosocial 
and emotional effects on the family as well as being costly for health services.

Preterm labour is defined by the World Health Organization as the onset of labour in a pregnancy before the completion of 37 weeks of gestation and after 20 weeks of gestation. As per ACOG criteria (1997), Preterm labour is defined as the occurrence of regular uterine contractions (four or more in 20 minutes (or) eight (or) more in 1 hour) and with cervical changes (effacement equal to (or) more than $80 \%$ and dilatation equal to (or) greater than $1 \mathrm{~cm}$ ). Lower limit of survival is 24 weeks of gestation in Western countries and it is more than 32 weeks in India. Upper limit of prematurity is 36 weeks.

In about $45-50 \%$ of cases of preterm labour, the aetiology remains obscure. So, attempts at prevention have not been very encouraging, but arrest of preterm labour continues to be the need of the hour. ${ }^{1}$ Obstetrician faces the challenge of survival of premature neonate as well as therapeutic alternatives available for management of preterm labour.

The aim of care around preterm birth does not always involve prevention of preterm labour and birth. In situation where clinical considerations make it desirable to prolong pregnancy, the primary outcome considered is time gained to-

- Seek advice from perinatal care.

- Institute therapy to improve lung maturity.

- If necessary move the mother to a centre with neonatal intensive care facilities.

Currently, main goal for use of tocolytic therapy is to delay the birth so as to allow the use of corticosteroids for accelerating foetal lung maturity and maternal transfer to a tertiary care centre and thereby reducing neonatal morbidity and mortality. ${ }^{2}$ By arresting preterm labour, we can reduce the maternal guilt and anxiety about the cause for preterm birth of their baby and financial burden of preterm birth and care around preterm birth for families and communities.

There are many number of tocolytic drugs, but unfortunately, none has been completely effective because of questionable efficacy and potentially serious side effects outweigh the use of many tocolytic agents. Beta adrenergic receptor agonists like Ritodrine, Terbutaline, Isoxsuprine and others like magnesium sulphate, calcium channel blockers (nifedipine), Prostaglandin synthetase inhibitors (Indomethacin), nitric oxide donors (glyceryl trinitrate) are tocolytic agents in use. In this study, comparison of effectiveness of oral nifedipine with transdermal nitroglycerin in the inhibition of preterm delivery is being done.

Comparison of oral nifedipine and transdermal nitroglycerin for tocolysis in preterm labour in the following effects-

1. Acute tocolytic effect.

2. Duration of prolongation of pregnancy.

3. Neonatal outcome.

\section{MATERIALS AND METHODS}

Study on tocolysis in preterm labour was conducted in Government Rajaji Hospital from December 2010 to November 2011; 100 women with preterm labour selected from the pregnant women attending antenatal OP and from labour ward from the Department of Obstetrics and Gynaecology, Government Rajaji Hospital, Madurai.

I selected only 100 cases with complaints of preterm labour with no complications. Patients with preterm labour who have complications like headache, hypotension and tachycardia are not included in this study.

I had divided the total cases of 100 into 50 cases in each group, since the study need a long-term followup. It is a comparison study and by the use of exclusion criteria the sample size was also small. Out of which, 50 women were recruited for oral nifedipine (Group I) and another 50 women were recruited for transdermal nitroglycerin patch (Group II).

Then based on the parity, gestational age, cervical dilation, cases were allocated equally and in non-random. Sample size calculation was not done for sake of convenience and this is the non-randomised controlled study.

\section{The Patients recruited for this Study fulfilled the} following Inclusion Criteria-

1. Singleton pregnancy with gestational age from 28 weeks to 36 weeks.

2. Regular painful uterine contractions minimum of two, every ten minutes and for more than 1 hour.

3. With intact membranes.

4. Cervical dilatation between $1 \mathrm{~cm}$ and $3 \mathrm{~cm}$.

5. No medical condition obviating medical therapy.

If the following conditions were present, those patients were excluded from the study.

\section{Exclusion Criteria}

1. Premature rupture of membranes.

2. Foetal distress.

3. Major foetal congenital anomalies.

4. Chorioamnionitis.

5. Antepartum haemorrhage.

6. Sensitivity or contraindication to nifedipine/nitrates.

All women meeting the eligibility criteria were properly informed about the aims of the study and those who agreed to participate signed a consent form. Those women who were diagnosed to have preterm labour were admitted in labour ward in the observational areas, where continuous monitoring was possible. A detailed history was obtained. Under aseptic precautions, general, systemic, speculum and pervaginal examinations were done. Baseline pulse, blood pressure and foetal heart rate were recorded. The findings were recorded on a predesigned proforma. Investigations like blood haemoglobin, blood grouping and Rh typing, urinealbumin, sugar, blood sugar, urea, serum creatinine and ultrasonography were done. Two doses of betamethasone (12 mg IM 24 hours apart) were administered to all cases. Prophylactic antibiotics were also given for prevention of infection.

50 patients were selected for oral nifedipine and were designated as Group I and the other 50 patients were selected for transdermal nitroglycerin patch and were designated as Group II. If and time needed for tocolysis, prolongation of pregnancy and the neonatal outcomes were observed. The results were tabulated in performed proforma and meticulously analysed. 


\section{Oral Nifedipine (Group-I)}

For women those allotted to oral nifedipine were initially administered $20 \mathrm{mg}$ of nifedipine in the form of $10 \mathrm{mg}$ tablets $\mathrm{x} 2$ tablets, and $10 \mathrm{mg}$ repeated after 30 minutes if there were contractions. Then $10 \mathrm{mg}$ oral nifedipine repeated every six hours till the contractions stop.

\section{Monitoring}

Maternal pulse rate, blood pressure, foetal heart rate and uterine contractions were monitored initially every 15 minutes for first two hours. Then every two hours for 6 hours and every 6 hours for 48 hours.

\section{Treatment was discontinued, if there was:}

1. Fall of BP less than $90 / 60 \mathrm{mmHg}$, (or)

2. If the pulse rate is more than $100 / \mathrm{mt}$, (or)

3. If the patient had premature rupture of membranes, (or)

4. If there was persistent uterine contractions even after 48 hours,

5. If signs of foetal distress.

Side effects like dizziness and nausea noted in a few patients.

The treatment was considered successful if uterine contractions subsided and tocolysis was achieved for more than 48 hours. This minimum time interval was chosen, because it was considered sufficient for the action of the administered steroids to decrease respiratory complications in premature neonate.

After contractions stopped, till 37 weeks of gestation patient was reviewed weekly once (or) followup done till delivery - if delivered before 37 weeks.

\section{Transdermal Nitroglycerin Patch (Group-II)}

Women in preterm labour were recruited for transdermal nitroglycerin study; transdermal nitroglycerin patch $(25 \mathrm{mg}$ ) (TTS-5) was directly applied to the skin of abdomen.

\section{Monitoring}

Throughout, maternal pulse, blood pressure and foetal heart rate were monitored every $15 \mathrm{mts}$. and occurrence of uterine contractions were also monitored every $15 \mathrm{mts}$. in the first two hours. Then, two hourly for $6 \mathrm{hrs}$. followed by $6^{\text {th }}$ hourly for 48 hours.

\section{Treatment was discontinued if}

1. Patient complaining of any headache,

2. Hypotension less than $90 / 60 \mathrm{mmHg}$,

3. Pulse rate more than $100 / \mathrm{min}$,

4. If the patient had premature rupture of membranes,

5. If there was persistent uterine contractions even after 48 hours,

6. If signs of foetal distress.

After contractions stopped patient was reviewed every week upto 37 weeks of gestation, otherwise till delivery if it occurs less than 37 weeks.

The results of the study is tabulated and analysed meticulously.

\section{Statistical Tools}

The information collected regarding all the selected cases were recorded in a Master Chart. Data analysis was done with the help of computer using Epidemiological Information Package (EPI 2010) developed by Centre for Disease Control, Atlanta.

Using this software range, frequencies, percentages, means, standard deviations, chi-square and ' $p$ ' values were calculated. Kruskal-Wallis chi-square test was used to test the significance of difference between quantitative variables and Yate's chi-square test for qualitative variables. A ' $p$ ' value less than 0.05 is taken to denote significant relationship.

\section{RESULTS AND ANALYSIS}

The study was designed with a total sample selected of 100 women who were in preterm labour, out of which 50 women in non-randomly allotted for oral nifedipine in Group I and another 50 women were non-randomly selected for transdermal nitroglycerin patch in Group II. All preterm labour women on study were given corticosteroids and prophylactic antibiotics. After inspection of the collected data from our study, the following results were observed.

Baseline characteristics of the two groups were comparable. Group I: Pregnant women with preterm labour were given oral nifedipine (50 cases).

Group II: Pregnant women with preterm labour were given transdermal nitroglycerin (50 cases).

\section{A: Profile of Cases Studied}

\begin{tabular}{|c|c|c|c|c|}
\hline \multirow{2}{*}{ Age Group } & \multicolumn{2}{|c|}{ Group I } & \multicolumn{2}{c|}{ Group II } \\
\cline { 2 - 5 } & No & $\%$ & NO & $\%$ \\
\hline$<20$ years & 12 & 24 & 6 & 16 \\
\hline 20-24 years & 17 & 34 & 19 & 38 \\
\hline 25-29 years & 14 & 28 & 16 & 32 \\
\hline 30 years above & 7 & 14 & 7 & 14 \\
\hline Total & $\mathbf{5 0}$ & $\mathbf{1 0 0}$ & $\mathbf{5 0}$ & $\mathbf{1 0 0}$ \\
\hline \multicolumn{3}{|c}{ Table 1. Age Distribution } \\
\hline
\end{tabular}

\begin{tabular}{|c|c|c|}
\hline Range & $18-35$ years & $18-32$ years \\
\hline Mean & 23.9 years & 24.0 years \\
\hline SD & 4.7 years & 4.1 years \\
\hline 'p' & \multicolumn{2}{|c|}{0.7165 Not Significant } \\
\hline
\end{tabular}

The age distribution of the two groups has no significant difference, (' $p$ '= 0.7165, Not Significant). The maximum number of patients in both groups fall in age group between 20-24 years, 34\% (17 out of 50) in Group I and 38\% (19 out of 50 ) in Group II; 24\% (12 out of 50) were teenagers in Group I when compared to Group II it was $16 \%$ (8 out of 50 ). In both the groups, $14 \%$ ( 7 out of 50 ) were more than 30 years of age. The mean age group in the study subject was 23.9 years in Group I and 24 years in Group II.

\begin{tabular}{|c|c|c|c|c|}
\hline \multirow{2}{*}{ Age Group } & \multicolumn{2}{|c|}{ Group I } & \multicolumn{2}{c|}{ Group II } \\
\cline { 2 - 5 } & No & $\%$ & No & $\%$ \\
\hline Booked & 23 & 46 & 19 & 38 \\
\hline Unbooked & 27 & 54 & 31 & 62 \\
\hline Total & 50 & 100 & 50 & 100 \\
\hline 'p' & \multicolumn{3}{|c|}{0.5433 Not Significant } \\
\hline \multicolumn{4}{|c}{ Table 2. Antenatal Care } \\
\hline
\end{tabular}


There is no significant difference in the Antenatal care received by the 2 groups of patients. ( $\mathrm{P}$ value $=0.5433$, not significant), 46\% (23 out of 50) belonged to Booked and 54\% (27 out of 50) belonged to Unbooked in Group I, whereas $38 \%$ (19 out of 50 ) belonged to Booked and 62\% (31 out of 50 ) belonged to Unbooked in Group II.

\begin{tabular}{|c|c|c|c|c|}
\hline \multirow{2}{*}{ Gravida } & \multicolumn{2}{|c|}{ Group I } & \multicolumn{2}{c|}{ Group II } \\
\cline { 2 - 5 } & No & $\%$ & NO & $\%$ \\
\hline Primigravida & 26 & 52 & 24 & 48 \\
\hline 2 & 11 & 22 & 13 & 26 \\
\hline 3 and above & 13 & 26 & 13 & 26 \\
\hline 'p' & \multicolumn{3}{|c|}{0.8961 Not Significant } \\
\hline \multicolumn{4}{|c|}{ Table 3. Parity } \\
\hline
\end{tabular}

There is no significant difference in the parity in both Group I and Group II (P value $=0.8961$, not significant). Primigravida comprised of about 52\% (26 out of 50) in Group I and 48\% (24 out of 50) in Group II. Multiparous women in pre-term labour comprised of about $48 \%$ (24 out of 50 ) in Group I and 52\% (26 out of 50) in Group II. Parity distribution was almost equal in both groups.

\begin{tabular}{|c|c|c|c|c|}
\hline \multirow{2}{*}{$\begin{array}{c}\text { History of } \\
\text { Preterm } \\
\text { Labour }\end{array}$} & \multicolumn{2}{|c|}{ Group I } & \multicolumn{2}{c|}{ Group II } \\
\cline { 2 - 5 } & No & \% & No & \% \\
\hline Yes & 11 & 22 & 9 & 18 \\
No & 39 & 78 & 41 & 82 \\
\hline 'p' & \multicolumn{3}{|c|}{0.8026 Not Significant } \\
\hline Abortion & 9 & 18 & 10 & 20 \\
Yes & 41 & 82 & 40 & 80 \\
No & \multicolumn{4}{|c|}{0.8126 Not Significant } \\
\hline 'p'
\end{tabular}

Pre-term labour in previous pregnancy was 22\% (11 out of 50) in Group I and 18\% (9 out of 50) in Group II. There is no significant difference in the history of pre-term labour between the 2 groups of patients $(p=0.8126)$. History of previous abortion was present in 18\% (9 out of 50) in Group I and $20 \%$ (10 out of 50 ) in Group II patients. There is no significant difference in both the groups of patients.

\begin{tabular}{|c|c|c|c|c|c|c|}
\hline \multirow{3}{*}{$\begin{array}{c}\text { Gestational } \\
\text { Age } \\
\text { (In Weeks) }\end{array}$} & \multicolumn{4}{|c|}{ No. of Cases } & \multicolumn{2}{|c|}{ Prolongation } \\
\hline & \multicolumn{2}{|c|}{ Group I } & \multicolumn{2}{|c|}{ Group II } & \multirow{2}{*}{$\underset{\text { I }}{\text { Group }}$} & \multirow{2}{*}{$\underset{\text { II }}{\text { Group }}$} \\
\hline & No & $\%$ & No & $\%$ & & \\
\hline $28-30$ & 9 & 18 & 6 & 12 & 32.8 & 21.8 \\
\hline $31-32$ & 19 & 38 & 16 & 32 & 24.8 & 14.8 \\
\hline $33-34$ & 17 & 34 & 21 & 42 & 14.0 & 13.8 \\
\hline $35-36$ & 5 & 10 & 7 & 14 & 4.8 & 7.7 \\
\hline Total & 50 & 100 & 50 & 100 & 20.74 & 14.1 \\
\hline & & na & & & & \\
\hline
\end{tabular}

Though there was not much significant difference in the gestational age on admission in both the groups, the time of prolongation of pregnancy varied considerably in both the groups.

$38 \%$ (19 out of 50 ) of Group I study subjects were in 31 32 weeks of gestation and 32\% (16 out of 50) in Group II study subjects were in 31 - 32 weeks of gestation; $10 \%$ in Group I were in more than 34 weeks and 14\% in Group II were in more than 34 weeks. Mean prolongation in Group I was 20.74 days. In Group II, it was 14.1 days.
Mean duration of prolongation of pregnancy varied with gestational age on admission, considerably both in Group I and Group II. When the gestational age was less than 30 weeks, the mean prolongation was 32.8 days in Group I and it was 21.8 days in Group II. When gestational age was between 31 - 32 weeks the mean prolongation was 24.8 in Group I, whereas in Group II it was 14.8 days. When gestational age was between 33 and 34 weeks, mean prolongation in Group I was 14 days and in Group II it was 13.8 days. When the gestational age was between 35 and 56 weeks, prolongation was 4.8 days in Group I and 7.7 days in Group II.

\begin{tabular}{|c|c|c|c|c|}
\hline \multirow{2}{*}{ Presentation } & \multicolumn{2}{|c|}{ Group I } & \multicolumn{2}{c|}{ Group II } \\
\cline { 2 - 5 } & No & $\mathbf{\%}$ & No & \% \\
\hline Head & 46 & 92 & 45 & 90 \\
\hline Breech & 4 & 8 & 5 & 10 \\
\hline 'p' $\mathrm{p}^{3}$ 0.5 Not Significant \\
\hline \multicolumn{3}{|c|}{ Table 6. Presentation } \\
\hline
\end{tabular}

The distribution of the presenting part in both the groups were equal. Majority of the patients in both the groups had cephalic presentation of $92 \%$ (46 out of 50) in Group I and $90 \%$ ( 45 out of 50 ) in Group II.

\begin{tabular}{|c|c|c|c|c|c|c|c|}
\hline \multirow{2}{*}{$\begin{array}{c}\text { Cervical } \\
\text { Effacement }\end{array}$} & \multicolumn{4}{|c|}{ No. of Case } & \multicolumn{2}{c|}{$\begin{array}{c}\text { Prolongation } \\
\text { (Mean) } \\
\text { (In Days) }\end{array}$} & \multirow{2}{*}{ 'p' } \\
\cline { 2 - 7 } & Group I & \multicolumn{2}{|c|}{ Group II } & \multicolumn{1}{|c|}{$\begin{array}{c}\text { Group } \\
\text { I }\end{array}$} & $\begin{array}{c}\text { Iroup } \\
\text { II }\end{array}$ & \\
\cline { 2 - 7 } & No & $\%$ & No & \% & \\
\hline $25 \%$ & 18 & 36 & 21 & 42 & 33.5 & 22.1 & $\begin{array}{c}0.0003 \\
\text { Significant }\end{array}$ \\
\hline $50 \%$ & 19 & 38 & 14 & 28 & 20.6 & 13.1 & $\begin{array}{c}0.0518 \\
\text { Not } \\
\text { significant }\end{array}$ \\
\hline $75 \%$ & 13 & 26 & 15 & 30 & 3.3 & 2.8 & $\begin{array}{c}0.3388 \\
\text { Not } \\
\text { Significant }\end{array}$ \\
\hline
\end{tabular}

Table 7. Cervical Effacement

Cervical effacement in both the groups had no significant difference; 36\% (18 out of 50) in Group I had 25\% effacement and $42 \%$ (21 out of 50) in Group II had 25\% effacement; 38\% (19 out of 50) in Group I and 28\% (14 out of 50) in Group II had 50\% effacement, 26\% (13 out of 50) in Group I and 30\% (15 out of 50) in Group II had 75\% effacement.

Cervical effacement considerably influenced on the mean prolongation of pregnancy; after tocolysis in both the groups, Group I had mean prolongation of pregnancy significantly when compared to Group II when the cervical effacement was $25 \%(p=0.003$, significant $)$.

\begin{tabular}{|c|c|c|c|c|c|c|c|}
\hline \multirow{3}{*}{$\begin{array}{l}\text { Cervical } \\
\text { Dilation } \\
\text { (In cms) }\end{array}$} & \multicolumn{4}{|c|}{ No. of Case } & \multicolumn{2}{|c|}{\begin{tabular}{|c} 
Prolongation \\
(Mean) \\
(In Days)
\end{tabular}} & \multirow[t]{3}{*}{ 'p' } \\
\hline & \multicolumn{2}{|c|}{ Group I } & \multicolumn{2}{|c|}{ Group II } & \multirow{2}{*}{$\begin{array}{c}\text { Group } \\
\text { I }\end{array}$} & \multirow{2}{*}{$\begin{array}{c}\text { Group } \\
\text { II }\end{array}$} & \\
\hline & No & $\%$ & No & $\%$ & & & \\
\hline$<1$ & 14 & 28 & 18 & 36 & 33.2 & 21.7 & $\begin{array}{c}0.0044, \\
\text { Significant }\end{array}$ \\
\hline 1 & 17 & 34 & 16 & 32 & 25.4 & 15.1 & $\begin{array}{c}0.0018, \\
\text { significant }\end{array}$ \\
\hline 2 & 10 & 20 & 8 & 16 & 11.0 & 4.0 & $\begin{array}{c}0.2341 \\
\text { Not } \\
\text { Significant }\end{array}$ \\
\hline 3 & 9 & 18 & 8 & 16 & 3.2 & 2.8 & $\begin{array}{c}0.645 \\
\text { Significant }\end{array}$ \\
\hline \multicolumn{8}{|c|}{ Table 8. Cervical Dilation } \\
\hline
\end{tabular}


In mean prolongation of pregnancy, Group I was having 33.2 days, whereas in Group II it was 21.7 days $(p=0.0044$, significant) when the cervical dilatation was less than $1 \mathrm{~cm}$. Mean prolongation with Group I was 25.4 days and 15.1 days in Group II ( $p=0.0128$, significant), when the cervical dilatation was $1 \mathrm{~cm}$. With $2 \mathrm{~cm}$ dilatation of cervix, mean prolongation was 11 days in Group I and 4 days in Group II. When the cervical dilation was $3 \mathrm{cms}$, mean prolongation with Group I was 3.2 days and with Group II was 2.8 days ( $\mathrm{p}=$ 0.0458, significant).

Mean prolongation with Group I was significant when compared to Group II, in case of cervical dilatation $1 \mathrm{~cm}$ or less than $1 \mathrm{~cm}$.

\begin{tabular}{|c|c|c|c|c|c|c|c|}
\hline \multirow{2}{*}{$\begin{array}{c}\text { Station of } \\
\text { Present- } \\
\text { ing Part }\end{array}$} & \multicolumn{3}{|c|}{ No. of Case } & \multicolumn{2}{|c|}{$\begin{array}{c}\text { Prolongation } \\
\text { (Mean) } \\
\text { (In Days) }\end{array}$} & \multirow{2}{*}{ 'p' } \\
\cline { 2 - 7 } & $\begin{array}{c}\text { Group } \\
\text { I }\end{array}$ & \multicolumn{2}{|c|}{$\begin{array}{c}\text { Group } \\
\text { II }\end{array}$} & $\begin{array}{c}\text { Group } \\
\text { I }\end{array}$ & $\begin{array}{c}\text { Group } \\
\text { II }\end{array}$ & \\
\cline { 2 - 7 } & No & $\%$ & No & $\%$ & & \\
\hline-3 & 20 & 40 & 12 & 24 & 29.2 & 15.25 & $\begin{array}{c}0.0011 \\
\text { Significant }\end{array}$ \\
\hline-2 & 21 & 42 & 29 & 58 & 20.43 & 15.54 & $\begin{array}{c}0.4982 \\
\text { Not } \\
\text { significant }\end{array}$ \\
\hline-1 & 9 & 18 & 9 & 18 & 2.67 & 1.13 & $\begin{array}{c}0.4138 \\
\text { Not } \\
\text { Significant }\end{array}$ \\
\hline \multicolumn{7}{|c|}{ Table 9. Station of Presenting Part } \\
\hline
\end{tabular}

There is no significant difference in the distribution of station of presenting part in both the groups. In both the groups $18 \%$ (9 out of 50 ) had presenting part at -1 station, and $82 \%$ ( 41 out of 50 ) in both the groups had the presenting part at and above -2 station. Mean prolongation of pregnancy was 29.2 days in Group I and 15.25 days in Group II ( $p=$ 0.0011 , significant). When the station was -2 mean prolongation with Group I was 20.4 days and with Group II was 15.5 days. Mean prolongation was 2.6 days in Group I and 1.1 day in Group II when the presenting part was at -1 station.

\section{B: Efficacy of the Two Drugs}

\begin{tabular}{|c|c|c|c|c|c|c|c|}
\hline \multirow{3}{*}{$\begin{array}{c}\text { Bishop } \\
\text { Score }\end{array}$} & \multicolumn{4}{|c|}{ No. of Cases } & \multicolumn{2}{|c|}{$\begin{array}{c}\text { Prolongation } \\
\text { (Mean) } \\
\text { (In Days) }\end{array}$} & \multirow[t]{3}{*}{ 'P' } \\
\hline & \multicolumn{2}{|c|}{\begin{tabular}{|l|} 
Group I \\
\end{tabular}} & \multicolumn{2}{|c|}{ Group II } & \multicolumn{2}{|c|}{\begin{tabular}{|l|l|} 
Group Group \\
\end{tabular}} & \\
\hline & No & $\%$ & No & $\%$ & I & II & \\
\hline Upto 4 & 37 & 74 & 36 & 72 & 26.9 & 17.9 & $\begin{array}{c}0.0023 \\
\text { Significant }\end{array}$ \\
\hline Above 4 & 13 & 26 & 14 & 28 & 3.3 & 2.5 & $\begin{array}{c}0.1572 \text {, Not } \\
\text { Significant }\end{array}$ \\
\hline \multicolumn{8}{|c|}{ Table 10. Bishop Score } \\
\hline
\end{tabular}

About 74\% (37 out of 50) in Group I and about 72\% (36 out of 50) had Bishop score upto 4, here the mean prolongation with Group I was 26.9 days and 17.9 days with Group II ( $p=0.0023$, significant). When the Bishop score was above 4, mean prolongation with Group I was 3.3 days and with Group II was 2.5 days ( $p=0.1572$, not significant).

\begin{tabular}{|c|c|c|}
\hline \multirow{2}{*}{ Variable } & \multicolumn{2}{|c|}{ Time Needed for Tocolysis } \\
\cline { 2 - 3 } & Group I & Group II \\
\hline Range & $2-12$ hours & $2-12$ hours \\
\hline Mean & 4.55 & 6.09 \\
\hline SD & 3.05 & 3.2 \\
\hline 'P' & \multicolumn{2}{|c|}{0.006, Significant } \\
\hline \multicolumn{2}{|c|}{ Table 11. Time Needed for Tocolysis } \\
\hline
\end{tabular}

Time needed for Tocolysis ranging between 2 - 12 hours in both the groups. Mean time needed for Tocolysis in Group I was 4.55 hours and in Group II it was 6.09 hours. ' $P$ ' value= 0.006 , significant.

\begin{tabular}{|c|c|c|c|c|}
\hline \multirow{2}{*}{ Complications } & \multicolumn{2}{|c|}{ Group I } & \multicolumn{2}{c|}{ Group II } \\
\cline { 2 - 5 } & No & \% & No & \% \\
\hline Dizziness & 1 & 2 & 2 & 4 \\
\hline Nausea & 2 & 4 & - & - \\
\hline Tachycardia & - & - & 2 & 4 \\
\hline Headache & - & - & 7 & 14 \\
\hline 'P' Table 12. Complications \\
\hline \multicolumn{3}{|c|}{ 0.0437, Significant } \\
\hline
\end{tabular}

There is a significant difference in the incidence of complications among the 2 groups of patients $p$ (0.0437). Among Group I it was about 6\% (3 out of 50) and in Group II $22 \%$ (11 out of 50 ). Side effect with nifedipine was dizziness and nausea. Headache was the main side effect seen with nitroglycerin. No major systemic complications were faced in Group I.

\begin{tabular}{|c|c|c|c|c|}
\hline $\begin{array}{c}\text { Gestational Age } \\
\text { at Delivery } \\
\text { (In Weeks) }\end{array}$ & \multicolumn{2}{|c|}{ Group I } & \multicolumn{2}{c|}{ Group II } \\
\cline { 2 - 5 } & No & $\mathbf{\%}$ & No & \% \\
\hline $28-30$ & 1 & 2 & 2 & 4 \\
\hline $30-32$ & 1 & 2 & 2 & 4 \\
\hline $32-34$ & 6 & 12 & 8 & 16 \\
\hline $34-37$ & 29 & 58 & 30 & 60 \\
\hline$>37$ & 13 & 26 & 8 & 16 \\
\hline Mean & \multicolumn{3}{|c|}{35.49 weeks } & 34.89 weeks \\
\hline P & \multicolumn{3}{|c|}{ 0.156 Not Significant } \\
\hline
\end{tabular}

When the gestational age at delivery was compared in both the groups, it differed significantly; $4 \%$ (2 out of 50 ) were delivered in less than 32 weeks in Group I, whereas 8\% (4 out of 50) were delivered in less than 32 weeks in Group II. In Group I 26\% (13 out of 50) were delivered after 37 weeks, it was $16 \%$ (8 out of 50 ) in Group II. Mean gestational age at delivery in Group I was 35.49 weeks, whereas in Group II it was 34.89 weeks.

\begin{tabular}{|c|c|c|c|c|}
\hline \multirow{2}{*}{$\begin{array}{c}\text { Duration of } \\
\text { Prolongation }\end{array}$} & \multicolumn{2}{|c|}{ Group I } & \multicolumn{2}{c|}{ Group II } \\
\cline { 2 - 5 } & No & \% & No & \% \\
\hline Same day & - & - & 2 & 4 \\
\hline 1 day & 1 & 2 & 3 & 6 \\
\hline 2 days & 4 & 8 & 9 & 18 \\
\hline 3-7 days & 11 & 22 & 7 & 14 \\
\hline 1 week - 2 weeks & 3 & 6 & 9 & 18 \\
\hline 2-4 weeks & 15 & 30 & 16 & 32 \\
\hline > 4 weeks & 16 & 32 & 4 & 8 \\
\hline Range & \multicolumn{3}{|c|}{$1-60$} & \multicolumn{2}{|c|}{$0-44$} \\
\hline Mean & \multicolumn{3}{|c|}{0.0193 , Significant } \\
\hline 'P' & \multicolumn{5}{|c|}{} \\
\hline \multicolumn{1}{|c|}{ Table 14. Duration of Prolongation } \\
\hline
\end{tabular}


The treatment delivery interval differed significantly in both the groups. About 4\% (2 out of 50) delivered on the same day in Group II, whereas no one had delivered on the same day in Group I; 6\% delivered in 1 - 2 weeks in Group I and $18 \%$ in Group II; $22 \%$ (11 out of 50 ) in Group 1 and 14\% (7 out of 50) in Group II delivered within 3 - 7 days. When delivery after 4 weeks was compared 32\% (16 out of 50) in Group I and 8\% (4 out of 50) in Group II, delivered after 4 weeks ( $p=0.0059$, significant).

\begin{tabular}{|c|c|c|c|c|}
\hline \multirow{2}{*}{$\begin{array}{c}\text { Treatment } \\
\text { Delivery Interval }\end{array}$} & \multicolumn{2}{|c|}{ Group I } & \multicolumn{2}{c|}{ Group II } \\
\cline { 2 - 5 } & No & $\mathbf{\%}$ & No & \% \\
\hline Upto 2 days & 5 & 10 & 14 & 25 \\
\hline$>2$ days & 45 & 90 & 36 & 72 \\
\hline Total & 50 & 100 & 50 & 100 \\
\hline 'P' & \multicolumn{3}{|c|}{0.0414, Significant } \\
\hline \multicolumn{3}{|c}{ Table 15. Acute Tocolytic Effect } \\
\hline
\end{tabular}

The acute tocolytic effect between the 2 groups was significantly different $(\mathrm{p}=0.0414$, significant). Only $10 \%$ (5 out of 50) in Group I delivered within 2 days, but in Group II it was $28 \%$ ( 14 out of 50 ); $90 \%$ ( 45 out of 50 ) had crossed the period of 48 hours for effective action of steroids in Group I. But in Group II only 72\% (36 out of 50) crossed the period of 48 hours.

\begin{tabular}{|c|c|c|c|c|}
\hline \multirow{2}{*}{ Birth Weight } & \multicolumn{2}{|c|}{ Group I } & \multicolumn{2}{c|}{ Group II } \\
\cline { 2 - 5 } & No & $\mathbf{\%}$ & No & \% \\
\hline$<2.5 \mathrm{kgs}$ & 29 & 58 & 34 & 68 \\
\hline$>2.5 \mathrm{kgs}$ & 21 & 42 & 16 & 32 \\
\hline Mean & \multicolumn{2}{|c|}{$2.32 \mathrm{kgs}$} & \multicolumn{2}{c|}{$2.19 \mathrm{kgs}$} \\
\hline 'P' & \multicolumn{3}{|c}{0.1778} \\
\hline \multicolumn{4}{c}{ Table 16. Birth Weight } \\
\hline
\end{tabular}

There is no much significant difference in the birth weight of the babies in both the groups. In Group I, mean birth weight was $2.32 \mathrm{~kg}$, whereas in Group II mean birth weight was $2.19 \mathrm{~kg}$.

\begin{tabular}{|c|c|c|c|c|c|}
\hline Apgar & \multicolumn{2}{|c|}{ Group I } & \multicolumn{2}{c|}{ Group II } & \multirow{2}{*}{ 'P' } \\
\cline { 2 - 5 } Score at & Mean & SD & Mean & SD & \\
\hline 1 minute & 5.02 & 0.96 & 4.46 & 1.09 & $\begin{array}{c}0.0072, \\
\text { Significant }\end{array}$ \\
\hline 5 minutes & 6.38 & 1.14 & 5.8 & 0.95 & $\begin{array}{c}0.0075, \\
\text { Significant }\end{array}$ \\
\hline \multicolumn{6}{|c|}{ Table 17. Apgar Score } \\
\hline
\end{tabular}

Babies born in Group I had mean Apgar 5.02 and in Group II mean Apgar 4.46 in 1 minute, ' $p$ ' value $=0.0072$ (significant); 5 minute Apgar was 6.38 in Group I babies and it was 5.8 in Group II babies, 'p' value= 0.0075 (significant).

\begin{tabular}{|c|c|c|c|c|}
\hline \multirow{2}{*}{$\begin{array}{c}\text { Neonatal } \\
\text { Morbidity } \\
\text { (NICU Admission) }\end{array}$} & \multicolumn{2}{|c|}{ Group I } & \multicolumn{2}{c|}{ Group II } \\
\cline { 2 - 5 } & No & $\%$ & No & $\%$ \\
\hline Yes & 7 & 14 & 16 & 32 \\
\hline No & 43 & 86 & 34 & 68 \\
\hline 'P' Table 18. Neonatal Morbidity \\
\hline \multicolumn{3}{|c|}{0.05 , Significant } \\
\hline
\end{tabular}

Admission in neonatal ward differed significantly. Only 7 babies (14\%) in Group I got admitted in neonatal ward, whereas in Group II 16 babies (32\%) got admitted. This indicates nifedipine successfully reducing the neonatal admission and had the better perinatal outcome.

\section{DISCUSSION}

On analysing the outcome of data, tocolysis with oral nifedipine is considered safe with good therapeutic efficacy compared to transdermal nitroglycerin patch.

When this data was compared with previous study, baseline characteristics did not differ significantly. ${ }^{3}$ In the study by Amorim et al (2009 - 11), pregnant women were aged between 18 and 40 yrs with singleton pregnancies. In our study, the patients in Group I between 18 and 35 yrs and in Group II between 18 and 32 years were recruited. Gestational age at inclusion was between 24 to 34 weeks in Amorim study. Gestational age at entry differed considerably in each study group. In the study by Taherian (2007), it was 26 - 36 weeks. In Kashanian (2005) study, gestational age varied from 26 - 34 weeks. Gestational age between 26 and 36 weeks were recruited in Ganla $(1999)^{3}$ study. Papatsonis ${ }^{4}$ (1997) study included the 20 - 33 weeks gestational age. In the study by Smith GN (2007), ${ }^{5}$ gestational age between 24 and 32 weeks were included. In Afifa et al (2007), ${ }^{6} 28$ weeks to 36 weeks were taken for study. In our study, the patients recruited had the gestational age from 28 to 36 weeks. Maximum number of patients fell in the gestational age group of 31 to 34 weeks (74\%), both in nifedipine and in nitroglycerin group.

Cervical dilatation in our study was in the range of $3 \mathrm{~cm}$ or less, whereas in the study by Amorim $(2009-11)^{7}$ cervical dilatation was $2-4 \mathrm{~cm}$ and bag full of water. In Afifa (2007) study, cervical dilatation was $0-4 \mathrm{~cm}$. In study by KOKs (1998), cervical dilatation was $2 \mathrm{~cm}$ (or) less. Cervical dilatation influenced much on the prolongation of pregnancy when cervical dilatation exceeded more than $2 \mathrm{~cm}$, tocolytic efficacy was minimal. Mean prolongation of pregnancy with nifedipine in the study by Agustin et al $(2011)^{8}$ was 5.8 days. In Afifa study with nitroglycerin patch, mean prolongation was 2 days.9,10 In our study when cervical dilatation was 3 $\mathrm{cm}$, mean prolongation of pregnancy with nifedipine was 3.2 days and with nitroglycerin was 2.8 days.

In the study by Amorim (2009), nifedipine $10 \mathrm{mg}$ sublingually given was repeated after 30 minutes. Then 20 mg orally every 6 hours for at least 24 hours. ${ }^{11,12}$ In our study $20 \mathrm{mg}$ nifedipine was given orally, followed by $10 \mathrm{mg}$ after 30 minutes and $10 \mathrm{mg}$ every 6 hours till the contractions stopped. In Amorim study (2009) Nitroglycerin patch used was $10 \mathrm{mg}$; in our study nitroglycerin transdermal patch 25 mg was used.

In study by Amorim (2009) no significant difference of frequency of side effects was presented by patients except for headache, which was about $30 \%$ who received nitroglycerin and $8.3 \%$ with nifedipine. In our study, headache occurred in 11 patients $(22 \%)$ who received nitroglycerin and dizziness $(2 \%)$ and nausea $(4 \%)$ in patients who had oral nifedipine. Because of minimal side effects, nifedipine is considered safer. Study by Agustin et al (2011) showed that nifedipine appeared to be an effective tocolytic agent and had improvement in neonatal outcome.13,14 
The success rate of acute tocolysis was $87.5 \%$ with nifedipine and $84.6 \%$ with nitroglycerin in Amorim (2009) Study. In the study conducted here, success rate of acute tocolysis with oral nifedipine was $90 \%$ and with nitroglycerin was $72 \%$.

In study by afifa etal2007 the time average needed for tocolysis was 5.8 hours with oral nifedipine and 6.6 hours with nitroglycerin. In our study, time needed for tocolysis was 4.55 hours for oral nifedipine and 6.09 hours for transdermal nitroglycerin patch.

Mean prolongation of pregnancy up to more than 4 weeks with nifedipine was $32 \%$ and with nitroglycerin was $8 \%$ in our study.

Tocolytic efficacy of oral nifedipine was comparatively better than nitroglycerin, because of better acute tocolytic effect, reduced maternal complications, ${ }^{15,16}$ good neonatal outcome and lower preterm delivery rate and with good prolongation of pregnancy.

Safety, efficacy, acceptability limits and the usage of a drug, nifedipine is considered to be safer for its ease of use with metabolism and elimination of drug with minimal side effects. While efficacy was studied, nifedipine acts as a good tocolytic for effective action of corticosteroids and to provide time for the patient to get transferred to tertiary neonatal care unit. $17,18,19$

As a secondary analysis, an economic evaluation of the trial was done. Cost of oral nifedipine is less when compared to transdermal glyceryl trinitrate, which is costlier. Because of all of these- good acute tocolytic efficacy, less maternal side effect, good neonatal outcome, less cost, nifedipine was superior to glyceryl trinitrate. The rapid and effective action obtained with nifedipine, its simplicity of administration and safety suggest that nifedipine makes major contribution to the management of preterm labour.

\section{SUMMARY}

In this study, Group I received oral nifedipine and Group II received transdermal nitroglycerin patch. The results were analysed and studied-

1. Age distribution between the two groups was found to be equal. Majority of the patients belonged to age group of 20 - 29 years.

2. Most of the patients in this study group were found to be unbooked.

3. Parity distribution was found to be equal in Group I and Group II. Half of them were found to be primigravida.

4. Previous history of preterm labour was present only in minority of patients.

5. Majority of the patients in the study groups were found to be in the gestational age between 31 - 34 weeks.

6. $92 \%$ in Group I had cephalic presentation and $90 \%$ in Group II had cephalic presentation; 8\% in Group I and $10 \%$ in Group II had podalic presentation.

7. From the above analysis, this study group has equal distribution of cases both in Group I and Group II as far as age, parity, booking, presentation, gestational age on admission, previous history of abortion and preterm labour were concerned-

1. Cervical Effacement at the Time of Treatment The more the effacement, lesser is the duration of prolongation of pregnancy both in Group I and Group II.
2. Cervical Dilatation at the Time of Treatment

When the cervical dilatation is $3 \mathrm{cms}$, mean prolongation of about 3.2 days with Group I and about 2.8 days with Group II.

3. Station of Presenting Part

There is no significant difference in the distribution of station of presenting part in both the groups. Duration of prolongation of pregnancy decreases when the station of the presenting part comes down in both groups. Bishop score of about $74 \%$ in Group I and $72 \%$ in Group II had Bishop score 4 or less than 4. When the Bishop score is more than 4 , mean duration of prolongation is less.

4. Time Needed for Tocolysis

Both in Group I and Group II- Time needed for tocolysis ranged from 2 - 12 hours.

5. Complications

Only 6\% of patients in Group I and 22\% in Group II had side effects. It shows, Group I has minimal side effects and it is safer.

6. Gestational Age at Delivery

About 26\% in Group I delivered after 37 weeks, whereas in 16\% in Group II delivered after 37 weeks.

7. Duration of Prolongation

In Group I, 32\% were delivered after 4 weeks, but in Group II only 8\% were delivered after 4 weeks.

8. Acute Tocolysis

When acute tocolytic effect was compared, it was $90 \%$ in Group I and 72\% in Group II.

9. Neonatal Outcome and Neonatal Morbidity When birth weight of babies was compared 58\% in Group I and 68\% in Group II had less than $2.5 \mathrm{~kg}$, and $42 \%$ in Group I and 32\% in Group II had birth weight more than $2.5 \mathrm{~kg}$.

\section{CONCLUSION}

When compared with nitroglycerin, nifedipine is found to be absolutely safe and successful in achieving complete tocolysis.

Nifedipine is not only good in acute tocolysis but also very effective in prolonging the pregnancy for more than 28 days when in comparison with nitroglycerin and it has minimal side effects. Neonatal outcome was good with nifedipine, because it had better Apgar and less morbidity in neonates. To conclude, oral nifedipine has a very good role to play in the treatment of acute tocolysis and for prolongation of pregnancy. So, it can be considered as the first line drug of choice.

\section{REFERENCES}

[1] Read MD, Wellby DE. The use of a calcium antagonist (nifedipine) to suppress preterm labour. Br J Obstet \& Gynecol 1986;93:933-7.

[2] King JF, Flenady VJ, Papatsonis DNM, et al. Calcium channel blockers for inhibiting preterm labour. Cochrance Database Syst Rev 2002;(2):CD002255.

[3] Ganla KM, Shroff SA, Desail S, et al. A prospective comparison of nifedipine and isoxsuprine for tocolysis. Bombay Hosp J 1999;41:259-62.

[4] Smith GN, Guo Y, Wen SW, et al. Secondary analysis of the use of transdermal nitroglycerin for preterm labor. Am J Obstet Gynecol 2010;203(6):565.e1-6. 
[5] Papatsonis DN, van Geijn HP, Ader HJ, et al. Nifedipine and ritodrine in the management of preterm labor: a randomized multicenter trial. Obstet Gynecol 1997;90(2):230-4.

[6] Smith GN, Walker MC, Ohlsson A, et al. Randomized double-blind Placebo-controlled trial of transdermal nitroglycerin for preterm labor. Am J Obstet Gynecol 2007;196(1):37.el-8.

[7] Amorim MM, Lippo LA, Costa AA, et al. Transdermal nitroglycerin versus oral nifedipine administration for tocolysis: a randomized clinical trial (in Portuguese). Rev Bras Ginecol Obstet 2009;31(11):552-8.

[8] Koks CA, Brolmann HA, de Kleine MJ, et al. A randomized comparison of nifedipine and ritodrine for suppression of preterm labor. Eur J Obstet Gynecol Reprod Biol 1998:77(2):171-6.

[9] Bisits A, Madsen G, Knox M, et al. The Randomized Nitric Oxide Tocolysis Trial (RNOTT) for the treatment of preterm labor. Am J Obstet Gynecol 2004; 191(3):683-90.

[10] Papatsonis D Flenady, V, Cole S, et al. Oxytocin receptor antagonists for inhibiting preterm labor. Cochrane Database Syst Rev 2005;(3):CD004452.

[11] Lima MM, Souza AS, Diniz C, et al. Doppler velocimetry of the uterine, umbilical and fetal middle cerebral arteries in pregnant women undergoing tocolysis with oral nifedipine. Ultrasound Obstet Gynecol 2009; 34(3):311-5.
[12] Smith GN, Walker MC, McGrath MJ. Randomised, double-blind, placebo controlled pilot study assessing nitroglycering as a tocolytic. Br J Obstet Gynaecol 1999; 106 (7):736-9.

[13] Lees CC, Lojacono A, Thompson C, et al. Glyceryl trinitrate and ritodrine in tocolysis: an international multicenter randomized study. GTN Preterm Labour Investigation Group. Obstet Gynecol 1999; 94(3): 403-8.

[14] Resnik R. Issues in the management of preterm labor. J Obstet Gynaecol Res 2005; 31(5):354-8.

[15] Thornton JG. The quality of randomized trials of tocolysis. BIOG 2006;113(Suppl 3):93-5.

[16] Taherian AA, Dehdar P. Comparison of efficacy and safety of nifedipine versus magnesium sulfate in treatment of preterm labor. I Res Med Sci 2007;12: 136-42.

[17] Kashanian M, Akbarian AR, Soltanzadeh M. Atosiban and nifedipine for the treatment of preterm labor. Int J Gynaecol Obstet 2005; 91 (1):10-4.

[18] Carr DB, Clark AL, Kernek K, et al. Maintenance oral nifedipine for preterm labor: a randomized clinical trial. Am J Obstet Gynecol 1999;181(4):822-7.

[19] Sayin NC, Varol FG, Balkanli-Kalplan P, et al. Oral nifedipine maintenance therapy after acute intravenous tocolysis in preterm labor. J Perinat Med 2004; 32(3):220-4. 